\title{
What is 'Representation'? - a Debate Between Tyler Burge and John McDowell (with a Reference to Daniel Dennett)
}

\author{
Sofia Miguens \\ University of Porto - Portugal \\ smoraismiguens@gmail.com
}

Received 28 February 2019; accepted 30 January 2020; published 23 December 2020*.

\begin{abstract}
In this article I try to bring out the different conceptions of representation which lie behind Tyler Burge's and John McDowell's approaches to perceptual experience. As I go along I relate their motivations for defending (or attacking) disjunctivism to such conceptions of representation. In the case of McDowell I look at the origins of his position in his criticism of Daniel Dennett's view of perception and consciousness in the 1980s-1990s. Further differences in the debate are traced back to diverging conceptions of the respective roles of philosophy and cognitive science when dealing with perception. Although it is not directly explored here, McDowell Kantian view of mind as active lies at the background of the dispute with Burge.
\end{abstract}

Keywords: perception; representation; judgement; Burge; McDowell

\section{Introduction}

This article is about a debate over the nature of perceptual experience which took place not long ago between Tyler Burge, a representationalist, and John McDowell, a disjunctivist. I believe that the Burge-McDowell debate, as I will call it, helps bring forth questions about the nature of representation which are often silenced in the discussions in current philosophy of perception. Such discussions often become locked into flavour-of-the-moment disputes. The very terminology generally used in such disputes (the talk of veridical perceptions, illusions and hallucinations as being mental representations of equal standing) is not neutral regarding their outcome. Even if they do not depict their debate as such, Burge and McDowell are discussing, in the debate, what should count as representation, and for which reasons. Burge is a representationalist in the sense that he takes mental states like veridical perceptions, illusions and hallucinations to be all mental representations to be treated on the same foot. They should be considered as such because that is how 'the science' (of perception) considers them. In 
other words, he shares the terminology and the assumptions of mainstream philosophy of perception. Although McDowell does not pursue his approach to perception in terms of comparisons between veridical perceptions, illusions and hallucinations, it is clear that he could not accept such framing of the questions, due to the conception of representation it implies. I will try to spell out where the difference lies.

As I analyse the debate, I come across discussions concerning so-called disjuntivism and try to uncover Burge's and McDowell's motivations for defending (or attacking) disjunctivism. I am also interested in connecting McDowell's position with Daniel Dennett's theory of consciousness, since one version of McDowell's position was formulated in criticism of Dennett. Also, I want to make clear, with the analysis of the debate, what philosophy of perception is not for people such as McDowell in contrast to someone like Burge. Namely, for McDowell, philosophy of perception is not (cognitive) science (of perception). This should become apparent as his opposition to Burge unfolds.

\section{The Burge-McDowell controversy}

The controversy between John McDowell and Tyler Burge was prompted by a 2005 Philosophical Papers article entitled "Disjunctivism and perceptual psychology" (Burge, 2005). ${ }^{1}$ In the article Burge accuses a number of disjunctivists (Paul Snowdon, John McDowell, Gareth Evans, Mike Martin and John Campbell) of defending a view that is incompatible with what is known from empirical science of perception, scolds disjunctivists for failing to understand fallibility and ultimately accuses them of giving expression to a parochially British concern with an outmoded problem, that of overcoming an empiricist veil-of-ideas skepticism. His final verdict, as restated in 2011, is that

Disjunctivism ignores science in specifying ordinary psychological kinds and in doing epistemology. It is a doctrinal and methodological aberration. Philosophical progress will continue to pass it by (Burge, 2011, p. 71).

Although it would be worth comparing the disjunctivist positions of all the authors mentioned above, here I will consider John McDowell only. It is his particular motivation for being a disjunctivist (which does not necessarily coincide with the motivations of the other authors mentioned) that I want to bring out in the context of his response to Burge.

Needless to say, getting clear about what one means by 'disjunctivism' is in itself a problem - positions range from considering disjunctivism 'mandatory' (McDowell's term) to seeing it as an 'aberration' (Burge's term). Burge does take the trouble to define disjunctivism as he is attacking it. He is extremely careful in doing so, since he believes the philosophers he criticizes are not. According to Burge's definition, disjunctivism is an idea about psychological explanation and type-sorting of mental states:

\footnotetext{
${ }^{1}$ The other elements of the controversy that I will be considering are McDowell, 2011, Burge, 2011, McDowell, 2013 a and McDowell, 2013b. For Burge's epistemology of perception, see also Burge, 1993. This is a great amount of material, with detailed proposals on both sides; naturally here I will be considering only some aspects.
} 
Disjunctivism claims that there is never an explanatorily relevant mental state type in common between (and specific to) a veridical perception and a referential perceptual illusion. (Burge, 2005, p. 25)

Disjunctivist as defined above is a very bad idea because such denial of a common type (a 'common factor') clashes head-on with the assumptions of what Burge calls 'the science', i.e. the psychology of vision:

The idea that perceptual states causally depend only on proximal stimulations, internal input, and antecedent psychological conditions is basic to the method of the science (...) So the methodology of all serious empirical theory of vision guarantees that given types of visual state can be veridical in some circumstances and non-veridical in others. (Burge, 2005, pp. 22-23).

For Burge, the disjunctivist claim is completely ungrounded philosophical apriorism, comparable to Hegel's claim 'that the number of planets is seven' (Burge, 2005, p. 29). According to him, a psychological explanation simply requires commitment to mental states and types of mental states, and these are typed in terms of representational content (Burge, 2005, p. 3). Of course representational content is 'an abstraction that helps type psychological kinds' (Burge, 2005, p. 67). As for representations, Burge considers them to be tokened and structured, instances of, or vehicles, like inner symbols, expressing representational contents (Burge, 2005, p. 67). Anyway, according to Burge, perception is representational in that it purports to be about something and to represent it as being a certain way (Burge, 2005, p. 3). In this it contrasts with what he calls sensing.

It is clear that Burge's view, and criticism, of disjuntivism is tied to his view of psychological explanation. It is as a claim concerning explanatorily relevant mental states that disjuntivism is 'an aberration'. Yet when McDowell defends disjunctivism he is not thinking of psychological explanation: he defends disjunctivism as being, in its most simple guise, a philosophical idea about the nature and status of appearances. This is an idea expressed by a disjunction and an idea which bears crucially on epistemology. The disjunction is the following:

an appearance is either a case of things being thus and so in a way that is manifest to the subject or a case of its merely seeming to the subject that that is how things are (McDowell, 2010, p. 244).

It is perhaps wise to look for a definition coming neither from Burge nor from McDowell. Here is Matthew Soteriou's characterization of disjunctivism, in his Stanford Encylopedia article on disjunctive theory of perception:

Perceptual experiences are often divided into the following three broad categories: veridical perceptions, illusions, and hallucinations. For example, when one has a visual experience as of a red object, it may be that one is really seeing an object and its red colour (veridical perception), that one is seeing a green object (illusion), or that one is not seeing an object at all (hallucination). Many maintain that the same account should be given of the nature of 
the conscious experience that occurs in each of these three cases. Those who hold a disjunctive theory of perception deny this. (Soteriou, 2014) ${ }^{2}$

Clearly, there is lack of agreement on what disjuntivism is. In particular, does it concern appearances (to the subject) or inner vehicles of representation? This does make a huge difference, since in the former case the notion would concern the personal level of perceiving agents whereas in the latter the level would be sub-personal. Much in the analyses that follow will concern this. Before I proceed, one cautionary note is in order: one problem with taking McDowell as an example of a disjunctivist, as I will do here, is that there are many strands in his current position on perception. Some of these concern interpretations of Kant, Hegel and Sellars, and thus issues which are not of central interest to many of the participants in the mainstream discussions in the philosophy of perception. But I will concentrate on two points for now, which one might think are closer to more general concerns of such discussions: the methodological distinction between epistemology of perception and cognitive science of perception and the representationalist (or conceptualist) view of perceptual experience. ${ }^{3}$ It is the first, I believe, that is at the heart of the clash between McDowell and Burge. The second element (the idea that perceptual experiences have representational content) is something Burge in fact simply takes for granted and agrees with, overlooking the fact that McDowell has withdrawn his earlier stronger claims (in response to Charles Travis, see his Avoiding the Myth of the Given, McDowell, 2009a). In other words, McDowell does not think of representational content as Burge does: McDowell's representationalis approach to perceptual experience is formulated for appearances to the subject. I believe McDowell's motivation for being a representationalist regarding perception is rather different from the ones at stake in the clash with Burge (see Miguens, 2017).

\section{Perception: Presentiment or presence}

McDowell's 1994 article The Content of Perceptual Experience (McDowell, 1994a) is one of the texts discussed by Burge in Disjunctivism and perceptual psychology. The article focuses on (early) Daniel Dennett, more specifically on Dennett's writings on consciousness prior to Consciousness Explained, ${ }^{4}$ entitled "Towards a Cognitive Theory of Conciousness", included in his 1978 book Brainstorms. Criticizing Dennett gives McDowell the pretext to put forward

\footnotetext{
${ }^{2}$ The most usual way of formulating acceptance or rejection of the common kind claim is to speak of good cases (i.e. veridical perceptions) and bad cases (i.e. illusions and hallucinations).

${ }^{3}$ This is not an ad hoc choice, since these are in fact the topics of McDowell's two 2013 Agnes Cuming Lectures at UCDublin (Can Cognitive Science Determine Epistemology? Response to Tyler Burge, and Are the Senses Silent? Response to Charles Travis). Video-recordings of the full lectures are available online (cf. McDowell, 2013a and McDowell, 2013b). Of course McDowell is a rather peculiar disjunctivist in that he is a representationalist. Cf. Soteriou 2014 for comparisons among disjunctivists regarding representationalism.

${ }^{4}$ Since Dennett's basic approach remains unaltered (Miguens, 2002), I will refer to his 1991 book Consciousness Explained.
} 
his own disjuntive conception of perceptual experience. ${ }^{5}$ The disjuntivist conception of experience comes out as an alternative to the view of perception that goes with Dennett's theory of content and consciousness.

For present purposes the main idea in Dennett's view of perception is that perceivings, or experiencings, are seemings, seemings to a subject that things are a certain way. As for what seemings are, Dennett's position is blunt: seemings are judgements. In other words, for Dennett, perceiving, e.g. seeing, is straight judging. ${ }^{6}$ Here are some examples from the 1991 book Consciousness Explained of what Dennett means by his claim that seeing is judging.

1. The Marilyn wallpaper (Dennett, 1991, pp. 354-355). I walk into a room and the wallpaper is a regular array of hundreds of Warhol-like Marilyns. I cannot possibly foveate and thus clearly see all Marilyns as Marilyns (as opposed to blobs), still I see a Marylin-covered wall. According to Dennett, seeing the Marilyn-covered wall is believing that the wall is covered with Marylins.

2. The pink neon ring (Dennett, 1991, p. 351, 363). In the illusion known as the neonspreading effect I look at a grid in which there are only black and red lines and I see a pink neon ring spreading over the region delimited by red-black intersections. There really isn't a pink ring, as it were, 'in the world', only black and red lines. My seeing the ring (i.e. the seeming to me that there is a pink ring) is simply judging that (or believing that) there is a pink ring, Dennett says. Again, the thing isn't, as it were, 'out there': one brain circuit is misled to distinguish a bounded region, whilst another comes up with a colour discrimination to label the region. Here is another exemple of the illusion:

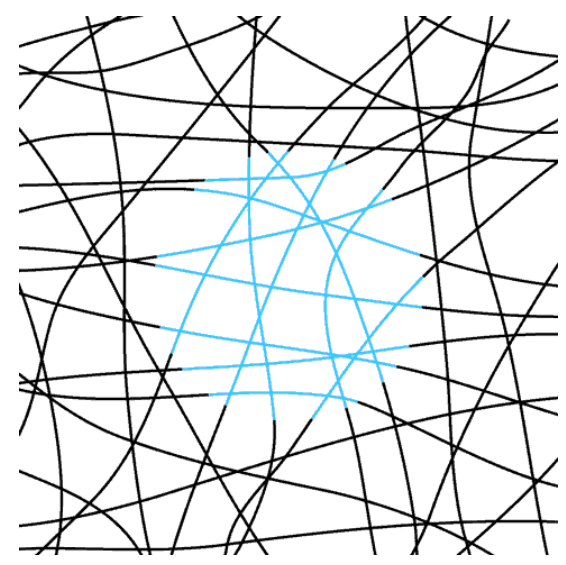

Figure 1. An example of the neon-spreading illusion

\footnotetext{
${ }^{5}$ In other places McDowell's presentation of his disjunctive view is prompted otherwise, e.g. by Myles Burnyeat's comparison between classical and Cartesian skeptic positions on the nature of appearances (see McDowell, 1986, Singular Thought and the Extent of Inner Space. This article is the other target of Burge, 2005). Another starting point is the Wittgensteinian discussion on criteria (see McDowell, 1998, Criteria, Defesability and Knowledge). About this see Miguens, 2019.

${ }^{6}$ He more often says 'believing'.
} 
This seeing (or perceiving)-is-believing move does a lot of work in Dennett's Multiple Drafts Model of consciousness. It is what ultimately allows Dennett to deal with decisive challenges to his theory of consciousness such as the Libet-cases of 'delayed awareness of intention' (where subjects' reports of conscious decisions supposedly lag behind cortical initiation of action, see Dennett, 1991, pp. 162-166) or the phi-phenomenon, i.e. cases of apparent movement (Dennett, 1991, p. 114). ${ }^{7}$ It is very important to keep in mind that Dennett deals with such cases by dealing with subjects' reports. Such reports are linguistic reports of seemings. It is such seemings that are taken by Dennett to be judgements. So a judgement in Dennett's sense is a case of a subject taking it that things are a certain way. It is this idea of judgement that he appeals to to counter the temptation to speak of 'filling in' by the brain when accounting for the cases above:

This idea of filling-in is common in the thinking of even sophisticated theorists, and it is a dead give away of vestigial Cartesian materialism. What is amusing is that those who use the term often know better, but since they find the term irresistible, they cover themselves by putting it in scare quotes. (Dennett, 1991, p. 344) ${ }^{8}$

According to Dennett, appealing to filling-in amounts to Cartesianism, that is to a view of the mental as necessarily centralized and conscious. Dennett thinks there is no need for that, no need to suppose there is a filled-in perceptual content before the 'mind's eye' - for there to be such content it is suficient that there is a judgement to that effect (a judgement that things are thus and so). This takes him to his conceptualist point: seemings to the subject are judgements (i.e. seemings are, as it were, a matter of conceiving, not a matter of perceiving). Now, although McDowell is much less interested in cognitive science per se than Dennett is, he apparently professes a somewhat similar conceptualism about perceptual experience. Namely, in Mind and World he claims "that things are thus and so is the content of the experience" (McDowell, 1994b, p. 26), or, more recently, in a more explicitly Sellarsian formulation, that experiencings or seemings are takings-as or claims (McDowell, 2013a). Conceptualism in this sense amounts to taking perceptual experience to have representational content, with the form 'that things are thus and so' (or better still: to be representational content). In fact, what comes next in this crucial passage of Mind and World is: "and it can also be the content of judgement".

Anyway, in the 1994 article one of McDowell's major criticisms of Dennett is that Dennett's idea of seeing as judging amounts to a presentiment view of perceptual experience: the way Dennett puts things, perceptual experiences turn out to be 'less than encounters with objects'. In other words, perceptual experiences are something 'inside our heads'. This is the first thing I want to look at.

\footnotetext{
${ }^{7}$ In an elementary case of the phi-phenomenon subjects report something like 'I see a light move across the screen' when there are only two separate flashes lit in rapid succession.

${ }^{8}$ For instance to account for the phi-phenomenon or the neon spreading illusion. He also uses the idea to resist what he sees as overinterpretations of the Libet cases (i.e. using them to deny free-will).
} 
According to McDowell, Dennett's conceptualism rests - in McDowell's terms, which I believe are quite important for understanding his debate with Burge -on a 'causal-enabling account of mindedness'. ${ }^{9}$ A causal-enabling account of mindedness concerns what Dennett calls the sub-personal, or sub-individual, level of agents, or perceivers.

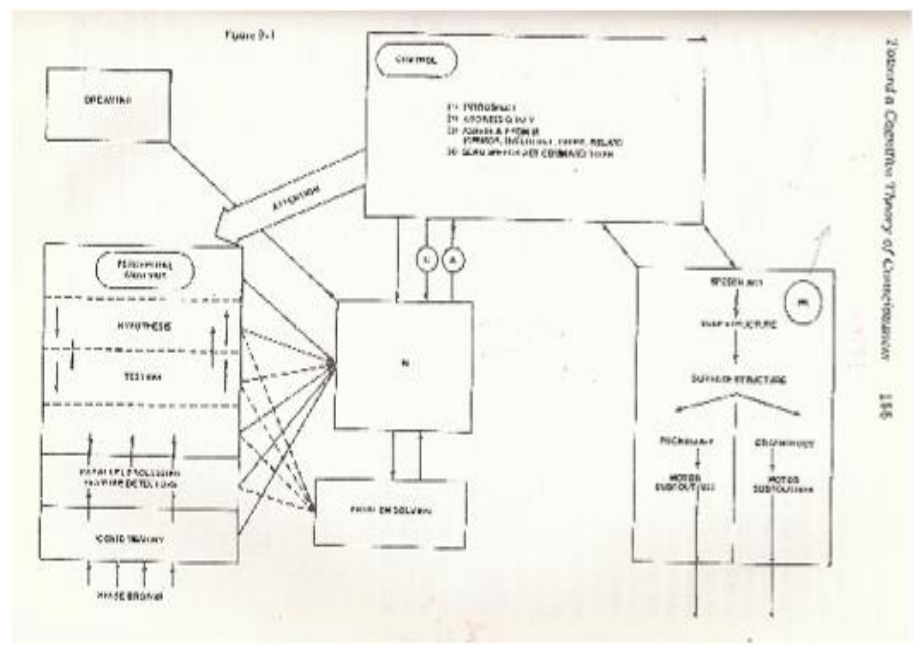

Figure 2. Dennett's 1978 cognitive model of consciousness in Toward a cognitive theory of consciousness. The boxes are 'modules' (Perception, Memory, Control, Attention, etc).

The arrows stand for flows of information.

Although McDowell praises Dennett for claiming that we have access to content (personallevel content, i.e., in Dennett's view, that which is reported in subjects' reports) and not to subpersonal content-bearers, i.e. vehicles of content, which are not introspectible by the perceiver, he sees a problem; as he later put it in his response to Burge, "In my paper [on Dennett] I urge that a good theory of the workings of a perceptual system yields accounts of what enables a perceiver to get into perceptual states, not accounts of what it is for a perceiver to be in those states" (McDowell, 2011, p. 250).

A causal-enabling approach to mindedness yields an account of what enables a perceiver to get into perceptual states; this means that its object is the workings of a perceptual system. Yet mistaking it for something else, namely mistaking it for what McDowell calls a constitutive account of mindedness, makes one oblivious of what it is for a perceiver to be in those states.

\footnotetext{
${ }^{9}$ In the exchange Burge repeatedly rejects the idea that perceptual psychology is a question of a causal-enabling, as opposed to constitutive, approach to perception: "The aim of the theory is to explain the structure of human and animal perception. The theory does not just explain a mechanism of perception or a set of enabling conditions for perception. The theory does not confine itself to providing an account of a causal chain of nonperceptual processes that precede or lie in the background of an individual's perceiving - and then stop there. The theory incorporates what is known about the accuracy and inaccuracy of whole-organism perception." (Burge, 2005, p. 21).
} 
This is not a Nagelian observation about the what-it-is-like-to-be of consciousness. That is not what McDowell is after. His point is closer to that of externalists than to phenomenal theorists of consciousness. McDowell's point is that a causal-enabling account of mindedness naturally leaves out the very mark of perceptual experience: its openness to the layout of reality. Openness to things being as they are, e.g. to presentness and particularity, is exactly what McDowell thinks is missing in Dennett. That this is missing makes Dennett's view amount to an identification of experiences with presentiments. To take McDowell's own exemple, let us say that I utter 'That cat is asleep' (McDowell, 1998, p. 341) [and there is a cat in front of me]. According to Dennett I find myself in a position to judge thus; I am struck, without knowing why, by (my own) taking things to be a certain way; I know nothing about the aetiology of such 'presentiment', I am just 'told something' by my inner processing machinery. McDowell thinks this cannot be right; experience does not have to be carried out to its object 'by an hypothesis' (McDowell, 1994a): in a perceptual experience the object of an experience is directly there for the thinker. Dennett's judgings-that may be something else - maybe thoughts, maybe fiction- but not perceptual experience: he conceives of perceptual experience as less than encountering objects, less than being acquainted with, or being presented with, the here and now.

I want to suggest that, in the exchange I am analysing, McDowell thinks Burge too is (mis)taking a causal-enabling account of perception (what he repeatedly calls 'the science') for a constitutive account. He is convinced that that is the only way to go (i.e. that there is only one account of perception, not two, see Burge, 2005, p. 343) and this makes him impervious to the fact that all of McDowell's claims concerning perceptual experience and the epistemology of perception belong in a constitutive account. McDowell's focus is on 'openness to the layout of reality', 'presence to one' and 'encounters with objects', not on the workings of the perceptual system of the agent. This focus delimits, for McDowell, the territory of philosophy of perception, in contrast (not in competition) with 'the science'. Needless to say, Burge is bound to disagree with the very idea of such a 'division of labour'. What else could perceptual psychology be, if not the science of perception? This is something Burge repeatedly asks. By that he means that perceptual pscyhology is not limited to sub-personal states; the subject's experience is part of its object:

The empirical psychology of vision is in the business of explaining the processes involved in individuals' perceptual representations of the physical environment. McDowell has given no genuine argument for regarding psychological explanation as non-literal. Similarly, he has given no argument for seeing it as concerned merely with the transactions of a subsystem and not with the empirical nature of visual perception by animals and humans. His claims about the science rest on a string of misunderstandings that elementar familiarity with the science would have prevented. (...) The main principles of the science have beeen in place since Helmholtz. Its maturation into a complex, well-established and mathematized body of knowledge has been evident over the last thirty years. The science is about the laws of visual perception, not about something else. (Burge, 2005, p. 50).

In other words, McDowell's distinction between 'causal-enabling' and 'constitutive' accounts of mindedness simply does not make sense to Burge. Notice though that this is not just a matter of who does what. Rather, it reflects directly on the fact that, in the controversy, McDowell keeps going back to the idea that 'good cases' involve more than veridical representation (he 
speaks of 'a more demanding condition that experiences being veridical') and that Burge does not see that. Exploring the epistemological significance of the good cases (i.e. the epistemological significance of 'openness to the layout of reality', or 'encounters with objects', in the good cases) is crucial for McDowell. For Burge, in contrast, good cases are simply more cases of representations, and they are not per se any different from non-veridical perceptual representations.

Here is how this reflects on McDowell's response to Burge's criticism number one in the controversy. According to Burge, the disjuntivists' denial that there are explanatorily relevant common states between veridical experience and the bad cases simply flies in the face of the science. It is up to cognitive science of perception to tells us whether perceptions and illusions are the same as inner representational states. And it does tell us that they are.

The background for this claim is what Burge sees as 'The bearing of the empirical psychology of vision on the individuation of perceptual states' (Point 4, Burge, 2005, p. 21). Considering that the paradigmatic problem of visual psychology is "to explain how information contained in these [retinal] arrays is transformed into representations (perceptions) of physical entities in the distal environment", given the fact that "the information available (...) significantly underdetermines the environmental distal causes of those registrations", one is faced with a problem of 'underdetermination'. Underdetermination takes a variety of forms, such as (Burge, 2005, p. 11) ambiguous figures, visual illusions, or visual completion. Basically, perceptual systems usually get things right, so the problem is in fact overcome by the visual system operating under certain principles in the formation of perceptions. "These principles constitute biases that convert proximal stimulation (...) into perception of the environment. Psychology is commited to some of the information being processed being representational - genuinely perceptual in that it represents objective matters and can be mistaken as well as veridical." (Burge, 2005, pp. 12-13). Two of Burge's examples are (Burge, 2005) lightness constancy and determining the slant of a textured surface from perceptual representations of texture features (Burge, 2005, pp. 14-18).

Thus the Proximality Principle (i.e. the idea that on any given occasion the total proximal input together with internal input into the system suffices to produce a given type of perceptual state) holds (Burge, 2005, p. 22). A corolary of the Proximality Principle as it bears on nonveridical perceptual states is that "Since relevantly different environmental distal conditions could yield the same type of proximal stimulation, a given type of perceptual state can be produced by different distal conditions." (Burge, 2005, p. 22). In light of this, Burge cannot but see the disjunctivists' denial of the common factor as ungrounded philosophical apriorism:

There is no getting around the fact that the basic kinds in perceptual psychology are (...) representational. Commitment to representations (...) as marking perceptual abilities is deeply embedded in the theory's objectives, methods and explanations (Burge, 2005, p. 19-20)

Step one of McDowell's rejoinder is that his disjunctivism regarding perceptual experience does not have to deny any common factor and it doesn't -things appearing to be a certain way is a common factor in perceptions and illusions. Also, he grants that Burge is right about the 
science. It is only that his claims about the Proximality Principle and the common factor concern precisely 'the science', not the epistemology of perception. Burge does not see that whereas 'the science' is concerned with the sub-personal level of perceivers, 'encountering objects', and thus 'openness to the layout of reality', is the foothold for the epistemology, an epistemology (i.e. disjuntivism) which is, McDowell says, 'mandatory'. Of course such a claim builds on a causal-enabling - constitutive distinction which Burge does not accept: he thinks that what he calls 'the science', i.e. perceptual psychology, does concern the whole subject, i.e. the whole animal and not merely 'transactions of a subsystem'.

The fact that perception does make knowledge about things available by placing them in view for us is crucial for understanding McDowell's response to Burge's accusation number two. Accusation number two concerns fallibility: 'disjunctivists don't understand fallibility', he says. So I will now go into McDowell disjuntivist account of how openness to the layout of reality (our 'encounters with objects', ${ }^{10}$ the externalism point) should bear on the conception of fallibility. Notice that when Burge speaks of fallibility he speaks (mostly) ${ }^{11}$ of veridical and non-veridical states of perceivers, i.e. of inner representations, sub-personal states taken to be representations. In contrast McDowell's views on fallibility are built around capacities of subjects and appearances. Now, these notions are not sub-personal notions. But before I look at what this means when it comes to the Burge- McDowell discussion of fallibility, I want bring in Dennett once again. I want to look at the appearance-reality distinction that goes with his conceptualism because it will help me bring out what McDowell is fighting against with his own way of approaching fallibility. ${ }^{12}$

\section{What can go wrong? Seemings and fallibility}

McDowell often speaks of experiencings, such as seeings, as seemings. A vocabulary of seemings is at work for both perceptual experience and epistemology (whenever McDowell is considering perception, he always has an eye on empirical knowledge ${ }^{13}$ ). Empirical knowledge is something Dennett is not so interested in (in fact, in matters epistemological, McDowell

\footnotetext{
${ }^{10}$ In fact McDowell mostly prefers 'facts'; I will not go into the ontological aspects of the discussion here.

${ }^{11}$ I am pushing the contrast. Burge's full story involves a difference between pattern-based representations and occurant-based representations (Burge, 2005, p. 2); the role of normal conditions and normal world for perceptions within that framework might bring him closer to McDowell's story about capacities. One very interesting point of Burge here is about objecthood as the mark of representation in his sense: "I believe that what is central in distinguishig perceptual representation from mere registration, or even mere sensation, is a certain type of objectification. To count as a perceptual system, the system must have objectifying capacities. Such capacities are perhaps most vividly exemplified by what is called representational constancies. These are capacities sistematically to represent a given property or object as the same despite significant variations in proximal stimulation." (Burge, 2005, p. 10)

${ }^{12}$ See Miguens, 2010.

${ }^{13}$ This is one important criticism of J. Benoist. See Miguens forthcoming, Les problèmes philosophiques de la perception.
} 
attri-butes to him 'a pre-Humean epistemological optimism' ${ }^{14}$ ). Still, a view of the status of seemings is an essential component of his view of content and consciousness given that such a view revolves around reports of seemings. One way to look at McDowell's way of dealing with seemings is seeing it as a way of avoiding an epistemological oddity that is part and parcel of Dennett's view and which he (Dennett) dubs first-person verificationism.

The issue is the following: is there such a thing as things seeming to me a certain way where I may be wrong about that? For Dennett, this could not be: once the difference between personal and sub-personal levels for a thinker, or a perceiver, is in place, Dennett's basic principle regarding the personal level is that there is no phenomenon as really seeming over and above the phenomenon of judging in one way or another that something is the case (Dennett, 1991, p. 364). This applies to reports of mental life (e.g. in the examples above: 'I see the Marylincovered wall', 'I see a pink ring', 'I am raising my arm right now', 'I see a light moving from left to right on the screen'). This is in fact the principle embedded in Dennett's use of the formulation 'seeing is believing'. In Dennett's own words, judgment is the key of phenomenology (by which he means the mental life of a thinker at the personal level): "phenomenology is "made of judgment, there is nothing more to phenomenology than that" (Dennett, 1991, p. 366).

Specifically this means that where it concerns her own awareness of things being a certain way, it is impossible for the subject to decide between appearance and reality: all she can do is say how things seem to her; this is what Dennett calls 'first person verificationism'. He sees this as a Wittgensteinian point. Interestingly, McDowell's (very different) disjunctivist position about appearance-reality distinction concerning 'inner space' is also supposed to be Wittgensteinian. ${ }^{15}$

Yet even if McDowell and Dennett share a vocabulary of seemings for the personal level, even if each of them claims a Wittgensteinian approach to seemings for himself, there is one allimportant difference: whereas for Dennett, perceptual seemings amount to being told (by inner information-processing machinery) that things are thus and so, and then the idea that there is no elbow room for the subject to distinguish between appearance and reality comes in, McDowell's 'space of seemings' is completely different. McDowell thinks of seemings, such as perceivings, as acts of capacities of a subject in an environment. Now, conceiving of seemings, such as perceivings, as acts of capacities of a subject in an environment, McDowell is precisely avoiding Dennett's subjectivizing of seemings and the associated internalization of the appearance-reality distinction. Avoiding an internalization of seemings is one crucial motivation for his disjuntivism. So it is not just the disregard for presence and particularity of experiential encounters with objects that makes Dennett's view of perception a presentiment

\footnotetext{
${ }^{14}$ For McDowell this ultimately means pre-Kantian, since Kant took Hume's point seriously (i.e. the idea that 'there is no satisfactory route' from the idea that 'no experience is intrinsically an encounter with objects', but rather 'glimpses of objective reality', to 'the epistemic position we are in', cf. McDowell, 1998, p. 344). As McDowell sees things, a Kantian viewpoint means precisely conceiving of every experience as being intrinsically an encounter with objects.

${ }^{15}$ As is Charles Travis' too (see Travis, 2013c), whose position on perception I compare with McDowell's (Miguens, 2017). In Criteria, Defeasability and Knowledge (McDowell, 1998a) the disjunctivist approach is put forward under the guise of a Wittgenstein-inspired dispelling of skepticism.
} 
view: it is also such internalization of the appearance-reality distinction. Anyway, stressing, as McDowell does, that it is capacities that can be fallible, not representational inner states that should be regarded as being straight veridical or non-veridical, has that further intent of doing away with what he calls 'a Cartesian conception of the inner world'. Such Cartesian conception may accompany a conception of seemings. According to the Cartesian conception, the inner world is a region of the world whose elements include states of affairs consisting in appearing to the subject that things are a certain way. An extra clause is decisive: that things thus appear to the subject on an occasion is the whole truth about the relevant state of affairs (McDowell, 2011, p. 244). This Cartesian conception of seemings may then come together with the apparently innocent idea that fallibility concerns a contrast between veridical and nonveridical representational states. McDowell's alternative view is that although perceivers are sometimes mistaken regarding seemings, that does not entail that when they are not mistaken, they are 'anywhere short of the facts' - in some cases (the good cases) that things are thus is simply being made manifest to the subject. There does not have to be any evidence on which to base an inference. This is how this idea bears on how one conceives of the appearancereality distinction:

But suppose we say - not at all unnaturally - that an appearance that such and such is the case can either be a mere appearance $\boldsymbol{o r}$ the fact that such and such is the case making itself perceptually manifest to someone. As before, the object of experience in the deceptive case is a mere appearance. But we are not to accept that in the non-deceptive case too the object of experience is a mere appearance and hence something that falls short of the fact itself. On the contrary, the appearance that is presented to one in those cases is a matter of the fact itself being disclosed to the experiencer. So appearances are no longer conceived as in general intervening between the experiencing subject and the world. (McDowell, 1998, p. 80)

Thus the disjunction that summarizes McDowell's perceptual disjunctivism is formulated as an idea about how to conceive of appearances:

We can express the idea [perceptual disjuntivism] with a disjunction: an appearance is either a case of things being thus and so in a way that is manifest to the subject or a case of its merely seeming to the subject that that is how things are (McDowell, 2010, p. 244).

The intuition can also be formulated in terms of factoring:

it is part of the point of my disjunctive conception of experience that having an aspect of objective reality perceptually present to one entails having it appear to one that things are a certain way. But that is not to say that having an aspect of objective reality perceptually present to one can be factored into some non-mental conditions and an appearance conceived as being the mental state it is independently of the non-mental conditions. The factoring fails; the state is the appearance it is only because it is a state of having something perceptually present to one. (McDowell, 2011, p. 251)

The point may be formulated in terms of appearances, of factoring, and also in terms of seemings. In the last case we have the following: perceptual experiences afford us seemings or appearings, i.e. takings-to-be that things are a certain way. Yet there is no genus seeming seeings, of which real seeings and merely seeming seeings are species (McDowell, 2013a). The second ones are 'experiences the subject would innocently take to be (e.g.) seeings'. If there was such a genus as seeming seeings, membership in the species would make no epistemic 
difference. There is an alternative way, though, of conceiving the relation between seeings and merely seeming seings, which is to take it that when an experience is a real seeing it does make an environmental reality present to the subject, and this makes all the difference epistemologically. It has a 'distinct epistemic significance' without which no proper account of perceptually based knowledge is possible. When things are given to one and the subject's conceptual capacities are operating, the subject is a position to know that things are a certain way. One can sometimes know by seeing - and this is knowing in no weak, defeasible sense, of knowing. In McDowell's words, experiences that are e.g. seeings afford conclusive warrants. This is what the good case provides, and this is one thing McDowell means when he says that more than veridical representation is at stake.

McDowell's story about fallibility is thus a story about capacities, a story with gives us an alternative to what he thinks is a faulty inference from fallibility:

A perceptual capacity is (...) a capacity - of course fallible - to get into positions in which one has indefeasible warrant for certain beliefs. (McDowell, 2005, p. 245).

Yet it is a

confusion to think that the idea of fallibility can intelligibly carry over to exercises of fallible capacities, as in Burge's remark 'I believe that all perceptual representations apply fallibly to their referents in any given instance'. (McDowell, 2011, p. 245, quoting Burge, 2005, p. 30. McDowell's italic in the quote)

Burge can only say this given the sub-personal touchstone of his conception of what representation is.

We may see McDowell's point about capacities, in his discussion of fallibility, as a point about grammar-according to such point, capacities are capacities of an agent, fallibility is a property of capacities, not of exercises of capacities. But one could also, going back to Dennett, put in in terms of cognitive theory: fallibility concerns the animal as a whole as a semantic engine and that should be the foothold for epistemology.

Dennett's distinction between syntactic and semantic engines is, according to McDowell in his 1994 article, a potentially rich idea which Dennett himself ended up subverting. According to the distinction, only (whole) animals are semantic engines - i.e. entities for whom the world is meaningful; their sub-personal parts are syntactic engines: unthinking, unjudging, unintelligent. This should mean, McDowell thinks, that only the animal (e.g. the person) can ever be 'told' something. The question then becomes (and he means this as a criticism of Dennett, in the 1994 article) how could then my inner processing machinery 'talk' to me (the whole me, as it were, in contrast to information flow taking place among functional sub-systems)?:

What could an information-processing device really tell an animal? What could an information-processing device really tell anything? It is essential to realize that the answer to this question can be, in fact is, "Nothing". (McDowell, 1994, p. 350)

If an animal is 'told' something it is 'told' something by its environment, not by its inner cognitive machinery. Apart from the specific criticism of Dennett, one very important point here for the McDowell-Burge controversy is that if in fact the animal is the sole semantic 
engine, then internal representations cannot be regarded as more than as-if representations. Of course, as-if representation has great practical importance; in McDowell's words,

Nobody knows how to make sense of an animals control mechanism, and connect it conceptually with the competence it is supposed to explain except by describing it as if it were what we know (McDowell, 1994, p. 350) it is not really, a semantic engine, interpreting inputs as signs of environmental facts and as output, directing behaviour so as to be suitable to those facts in the light of the animal's needs or goals. (McDowell, 1994, p. 351)

Still, we should not mistake sub-personal as-if representations (inner representations) for representation: only semantic engines have dealings with content, only semantic engines represent. But this is precisely one point which exasperates Burge about the 1994 article: "The appeal to representational content is not a metaphor in perceptual psychology" (Burge, 2005, p. 47), he says; one may, one should, in fact one is committed to by perceptual psychology to take certain inner states as representations. The point of the Proximality Principle is precisely that representations are needed to formulate laws of perceptual psychology.

It is not just the case that Burge's and McDowell's views on perception and representation clash: they are not even in a position to see each other's position as a reasonable one. While McDowell's view of fallibility - a central element of his perceptual disjunctivism and also of his epistemology of perception - allows for Burge being right about the science, it starts from the idea that being inner states of perceptual systems is not the only kind of intelligibility cognitive states have. One should sort acts of capacities in terms of epistemic significance, even if they belong together in terms of the kind of intelligibility they have for cognitive science, and then start doing epistemology. As possessors of epistemic significance experiencings (e.g. seeings) are not just veridical or non-veridical inner states of cognitive systems; they are also intelligible as acts of capacities of perceivers in an environmentally present reality and it is as such that they matter for epistemology. It is thus ultimately the conviction that there is a difference between the tasks of epistemology and cognitive science that underlies McDowell's claim that "the position I have recommended is not the position Burge attacks" (McDowell, 2010, p. 244). Whereas for McDowell what 'the philosophy' (to introduce an analogue for Burge's term 'the science') is involved with - e.g. understanding the epistemological significance of openness to reality in good cases or getting clear about the appearancereality distinction - is different than what cognitive science is involved in, for Burge, in his own terms, there is only one type of intelligibility ${ }^{16}$. Anyway after answering his own question in the first Agnes Cummin Lecture (Can Cognitive Science Determine Epistemology?) negatively, he goes after a variation of the question: Why does cognitive science need epistemology? His answer is that cogitive science needs epistemology for its conceptual apparatus to be

\footnotetext{
${ }^{16}$ It is not hard to realize, considering what I have been discussing, that McDowell's positions have much in common with the so-called wide perspectives on cognition (cognition embodied, embedded, extended and enacted), more specifically with extended and enactive orientations. Of course McDowell is interested in formulating his points in a purely philosophical fashion, and so regarding thought knowledge, and not cognition as seen from a scientific perspective. Yet the commonalities are there. Anyway McDowell himself, with such extended and enactive orientations, does not risk being accused of duplicating the work of science, as the rightful criticism in Marcin Miłkowski, Robert Clowes et al. inspepi2018, points out, emphasizing that the 'wide perspective is essentially a heuristics for building mechanistic explanations'.
} 
so much as intelligible, i.e. for us to know what we mean by concepts such as knowledge, justification or evidence, which naturally intersect the matters regarding perception and representation which i have been considering.

\section{Conclusion}

I will end by identifying a number of take-home messages that we may get from this recent controversy on perceptual experience. They are reminders of the fact that different uses of 'representation' may be conflated as discussions proceed. In fact, it is striking how participants in the discussions may very well be using the term in completely different senses and be totally unaware of that.

The first reminder is the following: if and when we take sub-personal states of perceivers to have representational content, i.e. when we chose to apply the term 'representation' to subpersonal states of agents and, like Burge, take them to be representations proper, we are in fact replacing a constitutive-account of mindedness with a causal-enabling account. We may believe that is the thing to do, as Burge certainly does. He does not see the point of any principled distinction between a constitutive account and a causal-enabling account of mindedness, or between philosophy of perception and cognitive science of perception. The question is, of course, whether we agree with that - whether philosophers and cognitive scientists should be dealing with the same issues when it comes to perception.

One consequence of the replacement of a constitutive-account of mindedness with a causalenabling account is losing touch with the idea that perception's openness to the layout of reality (at the level of the conscious agent) is for some philosophers the touchstone for epistemology and so for any questions regarding knowledge and justification. This leads to a second take-home message which comes up in the discussion of fallibility. It is almost always assumed that the contrast between veridical and non-veridical states of perceivers is the sole reference for conceiving of fallibility. Yet by thinking of fallibility in terms of veridical and non-veridical states we might be unknowingly making extra ('internalizing') assumptions regarding the appearance-reality distinction. Such assumptions may very well be ones we would otherwise dismiss as Cartesian. McDowell, for one, does not focus on states of perceptual agents; he focuses on rational capacities (of the whole agent, as it were). According to his alternative, perceptual capacities, albeit fallible, are still capacities to get into positions in which one may have indefeasible warrants for certain beliefs. He has his eyes on the epistemological position which may be developed here.

Although I did not get into that issue in this article, McDowell's position on fallibility goes along with a view of experience according to which we cannot make sense of mindedness as simply having representations, i.e. a purely inner mental realm of ideas in which we are confined. According to McDowell's (Kantian) view of experience, there is no mindedness prior to exerting judgement and judgement is always exerted regarding what is the case. So a Kantian view of experience such as McDowell's is a view of mind; not of a secluded inner realm of experiences but of mind in action, or active mind, and of mind in actuality. 
A final important point to keep from this controversy is that talk of 'two different kinds of intelligibility' does not necessarily involve rejecting the science, or even the Proximality Principle: it is ultimately a matter of taking cognitive science and philosophy (philosophy of perception, epistemology) to be projects of different nature. This is one thing that is definitely at the core of McDowell's response to Burge. Although he is a naturalist (a 'second nature naturalist'), McDowell is certainly not a Quinean naturalist - he does not see science and philosophy as continuous forms of inquiry. Of course, then this controversy simply exemplifies that different conceptions of what philosophy is (and what its relations to science is) are at work in the field of philosophy of perception. That certainly does not make things easier but it makes them even more interesting. But it would be the subject for another article.

\section{References}

Austin, J.L. (1962). Sense and Sensibilia. Oxford: OUP.

Beaney, M (ed.). (1997). The Frege Reader. London: Blackwel.

Boyle, M. (forthcoming). Kant on Logic and the Laws of Understanding. In S. Miguens and Ch. Travis, The Logical Alien At 20. Cambridge MA: Harvard UP.

Brogaard, B. (2014). Does Perception Have Content? Oxford: OUP.

Burge, T. (2003). Perceptual Entitlement. Philosophy and Phenomenological Research, 67, (3), 503-48.

Burge, T. (2005). Disjunctivism and Perceptual Psychology. Philosophical Topics, 33(1), 1-78.

Burge, T. (2010). Origins of Objectivity. Oxford: OUP.

Burge, T. (2011). Disjunctivism Again. Philosophical Explorations, 14(1), 43-80.

Byrne, A. and Logue, H. (2009). Disjunctivism - Contemporary Readings. Cambridge MA: MIT Press.

Dennett, D. (1978). Toward a Cognitive Theory of Consciousness. In D. Dennett, Brainstorms Philosophical Essays on Mind and Psychology (pp. 149-173). Montgomery, VT: Bradford Books.

Dennett, D. (1991). Consciousness Explained. Boston: Little Brown.

Dummett, M. (1973). Frege: Philosophy of Language. London: Duckworth.

Dummett, M. (1991). Frege and Other Philosophers. Oxford: Oxford University Press.

Frege, G. (1918/1993). “Der Gedanke”, Beiträge zur Philosophie des deutschen Idealismus, 2. In Logische Untersuchungen, hrsg. Günther Patzig, Göttingen, Vandenhoeck und Ruprecht (pp. 58-77). English translation: M. Beaney (ed.). (1997)., The Frege Reader. London: Blackwell.

Frege, G. Logik (1897). In Nachgelassene Schriften, H. Hermes, F. Kambartel and F. Kaulbach eds, Hamburg, Felix Meiner, (1983), pp. 137-163.

Haddock, A. and Macpherson, F. (2008). Disjunctivism: Perception, Action, Knowledge. Oxford: Oxford University Press. 
Kant, I. (1998). Critique of Pure Reason. Cambridge: Cambridge University Press.

Longuenesse, B. (1998). Kant and the Capacity to Judge. Princeton: Princeton University Press.

McDowell, J. (1986). Singular Thought and the Extent of Inner Space. In: P. Pettit and J. McDowell (eds.), Subject, Thought, and Context (137-168). Oxford: Clarendon Press.

McDowell, J. (1994a). The Content of Perceptual Experience. Philosophical Quarterly, 44(175), 190-205.

McDowell, J. (1994b). Mind and World. Cambridge: Harvard University Press.

McDowell, J. (1998a). Criteria, Defeasibility, and Knowledge. In J. McDowell Meaning, Knowledge, and Reality (pp. 369-394). Cambridge: Harvard University Press.

McDowell, J. (1998c). Meaning, Knowledge, and Reality. Cambridge: Harvard University Press.

McDowell, J. (2009a). Avoiding the Myth of the Given. In: J. McDowell (ed.), Having the World in View. Cambridge: Harvard University Press.

McDowell, J. (2009b). Conceptual Capacities in Perception. In: J. McDowell (ed.), Having the World in View. Cambridge: Harvard University Press.

McDowell, J. (2009c). Sensory Consciousness in Kant and Sellars. In: J. McDowell (ed.), Having the World in View. Cambridge: Harvard University Press.

McDowell, J. (2009a). The disjunctive conception of experience as material for a transcendental argument. In: J. McDowell (ed.), The Engaged Intellect. Cambridge: Harvard University Press.

McDowell, J. (2009b). Experiencing the World. In: The Engaged Intellect Cambridge, Harvard University Press.

McDowell, J. (2010). Tyler Burge on Disjunctivism. Philosophical Explorations 13(3), 243-55.

McDowell, J. (2013a). Can Cognitive Science Determine Epistemology? (Response to Tyler Burge). Retrieved from http: //www.youtube.com/watch?v=m8y8673RmII.

McDowell, J. (2013b). Are the Senses Silent? (Response to Charles Travis). Retrieved from http://www.youtube. com/watch?v=fBQHEGg5JSo.

McDowell, J. (2013). Perceptual experience: both relational and contentful. European Journal of Philosophy 21, 144-157.

Miguens, S. (2002). Uma Teoria Fisicalista do Conteúdo e da Consciência - Daniel Dennett e os debates da filosofia da mente. Porto: Campo das Letras.

Miguens, S. (2010). Trois perspectives sur la distinction apparence-réalité dans la expérience consciente. Rue Descartes 63, 18-30.

Miguens, S. (2010). A crítica de J. McDowell à concepção dennettiana de percepção. Revista de Filosofia Aurora (Brasil), 22 (30), 195-214.

Miguens, S. and Cadilha, S. (2014). John McDowell - uma análise a partir da filosofia moral, Lisboa: Colibri.

Miguens, S. (2017). Les problèmes philosophiques de la perception. In R. Moati \& D. Cohen-Lévinas (eds.), Lire Le Bruit du sensible de Jocelyn Benoist. 
Miguens, S. (2017). Apperception or environment - J. McDowell and Ch.Travis on the nature of perceptual judgement. ConTextos Kantianos 6, 79-92.

Miguens, S. (2018). Is seeing judging? Radical contextualism and the problem of perception. In: D. Zapero, E. Marchesan (eds.), Objectivity, Truth and Context (pp.124-158). London: Routledge.

Miguens, S. (2019). Temptation and Therapy-Wittgensteinian responses to other minds skepticism. Wittgenstein Studien 10(1), 227-239.

Milkowski, M., Clowes, R., Rucińska, Z., Przegalińska. A., Zawidzki, T., Krueger, J., Gies, A., McGann, M., Afeltowicz, Ł., Wachowski, W., Stjernberg, F., Loughlin, V and Hohol, M. (2019). From Wide Cognition to mechanisms: the silent revolution. Frontiers in Psychology 9(2393).

Shear, J. (ed.), (2013). Mind, Reason and Being in the World - the McDowell-Dreyfus debate. London, Routledge.

Soteriou, M. (2014). The Disjunctive Theory of Perception. In: E. N. Zalta (ed.), The Stanford Encyclopedia of Philosophy retrieved from http:// plato.stanford.edu/archives/sum2014/entries/perception-disjunctive/.

Travis, Charles, (2013a). The silence of the senses. In: Travis, Perception - Essays After Frege (2358). Oxford: OUP.

Travis, Ch. (2013b). Frege, Father of Disjunctivism. In: Travis, Perception - Essays After Frege (pp. 59-89). Oxford: OUP.

Travis, Ch. (2013c). While Under the Influence. In: S. Miguens and G. Preyer (eds), Consciousness and Subjectivity (pp. 147-169). Frankfurt, Ontos Verlag. Reprinted in (Travis, 2013), extensively revised.

Travis, Ch. (2014). The Preserve of Thinkers. In B. Brogaaard (ed.), Does Perception Have Content? (pp. 138-178). Oxford: OUP.

Travis, Ch. (2018). Their Work and Why They Do It. In E. Zapero \& D. Marchesan (eds.), Context, Truth and Objectivity. Essays on Radical Contextualism (pp. 205-248). New York \& London: Routledge.

Sofia Miguens is a Full Professor at the Department of Philosophy of the University of Porto, a researcher, as well as the founder and Principal Investigator of a research group Mind, Language and Action Group (MLAG) at the same university. She is author of seven books and editor of several others. She has published numerous articles, review articles and book chapters in Portuguese, English and French on topics in philosophy of mind and language; epistemology and cognitive science; moral and political philosophy and history of 20th century philosophy in its diverse traditions. 